\title{
EFFECTS OF THROMBIN AND PLATELET CONCENTRATIONS AND OF CLOT RETRACTION ON FIBRIN STRAND WIDTHS ${ }^{1,2}$
}

By RICHARD W. GREENE with the TECHNICAL ASSISTANCE of JANET McCONAUGHY

(Front the Department of Medicine, State University of New York, Upstate Medical Center, Syracuse, $N$. Y.)

(Sutmitted for publication December 11, 1953; accepted November 10, 1954)

Stübel in 1914 (1) first noted with an ultramicroscope that the fibrin strands produced from hemophilic blood are thicker than from normal blood. He attributed the thicker strands to the slower rate of clotting in hemophilic blood. Later in the same year Howell (2) performing similar kinds of experiments reported an experiment in which cat's plasma was clotted with thrombin: "A large amount of thrombin caused very rapid clotting with the production of small but distinct needles, while with a small amount of thrombin the clotting was slow and the needles were relatively large." In 1947, Ferry and Morrison (3) reported a similar microscopic observation in which decreasing thrombin concentration produced larger fibrin strands. They observed this at $\mathrm{pH}$ 6.0 since at $\mathrm{pH} 7.0$ the strands were too fine to be seen. Morrison and Scudder (4) working at $\mathrm{pH} 6.4$ believed there was no change in the thickness of the fibrin strands with varying thrombin concentrations. This was based on electron microscope photographs. A light scattering method for the determination of the average fibrin strand width has been reported previously from this laboratory (5). With this technique it is now possible to examine the effect of thrombin concentration on fibrin strand width in more detail.

Although numerous papers have been written on the relation of platelets to clot retraction ${ }^{3}(7$,

1 These studies were aided by a contract (NONR 12800) between the Office of Naval Research, Department of the Navy, and the State University of New York. This contract was supported jointly by the Office of Naval Research and the Atomic Energy Commission.

2 Presented in part before the Forty-Fifth Annual Meeting of the American Society for Clinical Investigation held in Atlantic City, New Jersey, May 4, 1953.

3 Clot retraction is considered to be a process separate and distinct from syneresis (6). The latter is the contraction of a colloidal gel and it is never as extensive and is much slower than clot retraction.
8), until recently it has not been possible to study the effect of platelets on fibrin strand size without the interference of clot retraction. This has been due to the lack of appreciation of the so-called serum factor. In 1951, Ellicott and Conley (9) showed that clots formed from purified fibrinogen and thrombin with washed platelets present would not retract. However, if a small amount of serum (or bovine albumin or gum acacia or egg white) was also in the clotting mixture, retraction occurred. Thus, by omitting the serum factor from the clotting mixture, the effect of platelets on the unretracted clot can be studied. Earlier writers (10-12) believed that during clot retraction lateral aggregation of the fibers occurred to give shorter and thicker strands. But no studies with the ultramicroscope $(13,14)$ or electron microscope $(15,16)$ have shown that, after coagulation has taken place, there is actually a shortening and thickening of the fibers during retraction. The use of the light scattering method offers an unique opportunity to study the effect of retraction on the width of the fibers since the clot is not disturbed while the measurements are being made.

In the studies to be reported herein, the effects of thrombin, platelet concentration and clot retraction on the width of the fibrin strands are demonstrated using a light scattering method. These findings are discussed in the light of current knowledge in this area.

\section{MATERIALS AND METHODS}

The light scattering method, preparation of samples, and analytical techniques have been reported previously (5). The following represents additions and revisions pertinent to this investigation:

Fibrinogen solutions from Fraction $I$. In some experiments human Fraction $I *$ was used as well as bo-

4 The human Fraction I, prepared by E. R. Squibb Sons, was kindly given to us by the American National Red Cross through the courtesy of Dr. Sam T. Gibson. 
vine Fraction I. Laki's method (17) of purifying Fraction I gave protein solutions which were 90 to 95 per cent clottable.

Thrombin. Upjohn bovine topical thrombin was used with both fibrinogen and plasma. The thrombin unit was reasonably near that defined by Seegers and Smith (18) -1 unit clotting a standard fibrinogen solution (with 2 per cent acacia [19] present) in $14.0 \pm 2 \mathrm{sec}$. No attempt was made to adjust the thrombin unitage to exactly 15 seconds since in any one experiment serial dilutions were made from the same thrombin preparation.

Platelet preparations. Platelet suspensions were prepared from fresh human blood in which either citrate (1 part of .109 molar sodium citrate plus 9 parts venous blood) or Sequestrene ${ }^{5}$ was used as the anticoagulantthe latter according to the method of Dillard, Brecher, and Cronkite (20). The addition of Triton ${ }^{\circ}$ as described by Minor and Burnett (21) was found advantageous in facilitating the resuspension of platelets after their centrifugation. Instead of centrifuging the red and white blood cells, high molecular weight dextran? (22) was used occasionally to increase the erythrocyte sedimentation rate. But excessive numbers of red cells often remained in the platelet containing supernatant plasma. The combination of Triton and dextran in plasma appeared to inhibit clotting completely or to give poorly formed clots.

"Serum factor." If clot retraction is desired in clotting mixtures containing only fibrinogen, thrombin, and platelets, a small amount of "serum factor" must be present (9). It was found that neglecting the saline washing of centrifuged platelets provided adequate "serum factor." Therefore these platelets were not truly "washed" but only concentrated and suspended in saline. It is concluded that minute amounts of calcium ion, said to be necessary for clot retraction (7), must have been present as a contaminant in the clotting mixture as it was never found necessary to add extra amounts of this ion. In determining the fibrin strand size of clots prepared from fibrinogen in the presence of platelets, no correction was made for the light scattering due to the platelets. The reason for this is given below. In experiments using fresh plasma containing platelets, platelet-free plasma samples were used as a blank in the manner previously described (5).

\section{RESULTS}

\section{The effect of thrombin concentration}

Using bovine Fraction I, the effect on fibrin strand width by varying the thrombin concentration between .02 and 0.5 units per cc. was studied.

\footnotetext{
- Supplied by courtesy of Alrose Chemical Co., Providence, $R$. I.

- Supplied by courtesy of Rohm and Haas Co., Philadelphia 5, Pa.

7 Prepared by Pharmacia Laboratories, Inc., New York 17, N. Y.
}

TABLE I

The effect of thrombin concentration on the fibrin strand radii

\begin{tabular}{|c|c|c|c|c|c|c|}
\hline \multirow[b]{2}{*}{$\mathbf{p H}$} & \multirow{2}{*}{$\begin{array}{l}\text { Fibrin } \\
\text { conc. } \\
g m . / L \text {. }\end{array}$} & \multicolumn{5}{|c|}{$\begin{array}{l}R \text { in Ångstroms at various thrombin } \\
\text { conc. in units per } c c .\end{array}$} \\
\hline & & 0.5 & 0.3 & 0.1 & 0.05 & 0.02 \\
\hline $\begin{array}{l}7.24 \\
7.24 \\
7.22 \\
7.22 \\
7.25 \\
7.34 \\
7.34 \\
7.34 \\
7.34 \\
7.30 \\
7.30 \\
7.30\end{array}$ & $\begin{array}{l}0.22 \\
0.22 \\
0.40 \\
0.40 \\
0.33 \\
0.68 \\
0.45 \\
0.34 \\
0.27 \\
0.31 \\
0.21 \\
0.125\end{array}$ & $\begin{array}{l}400 \\
400 \\
600 \\
650 \\
\\
600 \\
550 \\
475 \\
510 \\
400 \\
360 \\
350\end{array}$ & $\begin{array}{l}470 \\
440 \\
650 \\
700 \\
570 \\
625 \\
575 \\
575 \\
560 \\
500 \\
450 \\
450\end{array}$ & $\begin{array}{l}\mathbf{5 8 5} \\
\mathbf{5 5 0} \\
700 \\
\mathbf{7 5 0} \\
\\
\mathbf{7 0 0} \\
\\
\mathbf{6 0 0} \\
\mathbf{5 6 5} \\
\mathbf{5 1 0} \\
\mathbf{4 6 0} \\
\mathbf{5 8 0}\end{array}$ & $\begin{array}{l}850 \\
755 \\
625 \\
700 \\
590 \\
430 \\
598\end{array}$ & $\begin{array}{l}775 \\
640 \\
865 \\
850 \\
710 \\
825 \\
755 \\
850 \\
750 \\
\\
800 \\
650\end{array}$ \\
\hline
\end{tabular}

As the thrombin concentration decreased from 0.5 to .02 units per cc., in any one experiment in which the same preparation of fibrinogen was used, there was a consistent increase in the radii of the strands (Table I). The variation in the radius from one fibrinogen preparation to the next without de-

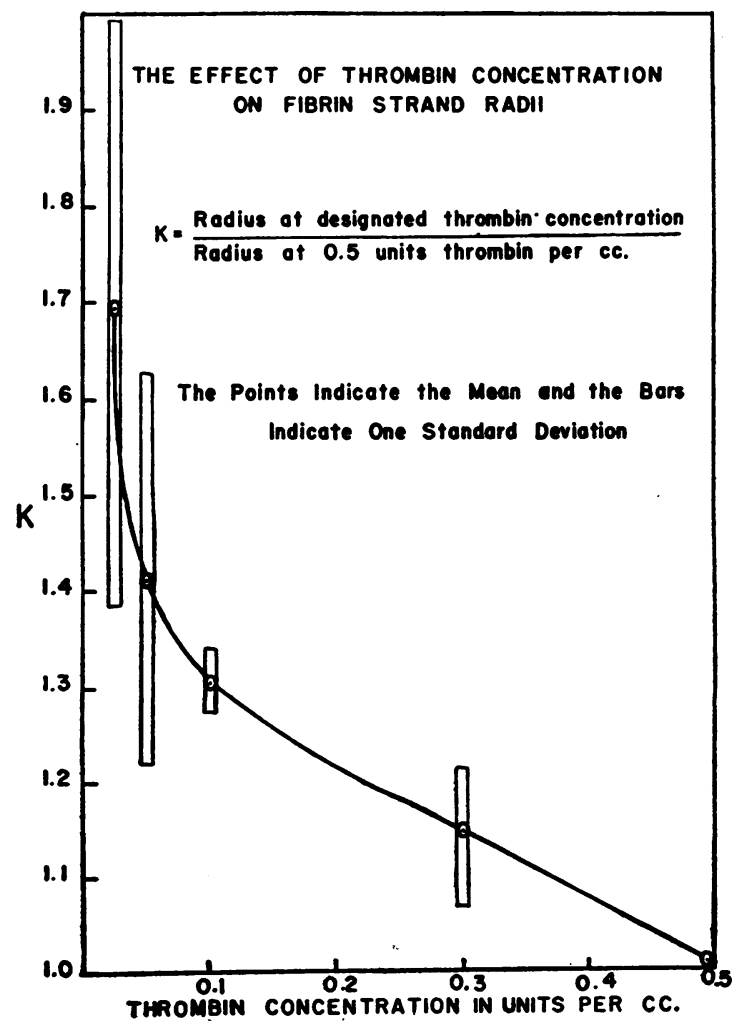

Fig. 1. The Efrzct of Thromorn Concentration on Fibrin Strand Size

As the thrombin concentration is decreased, the radii of the strands are increased. 
pendence on fibrinogen concentration between .1 to $1.0 \mathrm{gm}$. per liter was previously described (5). Therefore, in order to compare one experiment with another, proportionate increase in the radius rather than absolute increase was used. The radius at 0.5 units of thrombin per cc. was taken as unity. And the ratio of the radius at other thrombin concentrations to the 0.5 unit value was designated as $\mathrm{K}$ (Figure 1). The points indicate the mean, and the bars indicate one standard deviation. It can be seen clearly that as the thrombin concentration decreases, the average width of the fibrin strand increases. If the thrombin concentration is lowered much below .01 units per cc., incomplete clotting occurs.

It was found that, if the same fibrinogen solution between extremes of 0.1 and $1.0 \mathrm{gm}$. per liter is clotted with 0.3 units of thrombin per cc. or with 0.02 units of thrombin per cc., one obtains exactly the same weight of fibrin. This is in contrast to Morrison's work (23). However, his critical experiment on this point was at $\mathrm{pH} 6.34$, whereas in ours, the $\mathrm{pH}$ was between 7.0 and 7.5.
The readings were made one hour after adding the thrombin to the fibrinogen solution at $24^{\circ}$ to $28^{\circ} \mathrm{C}$., and no significant differences were seen if four-hour readings were taken. Actually, the rate of formation of a visible clot is much slower at the lower thrombin concentrations-at 0.3 units about 3 to 5 minutes are required and at 0.02 units about 8 to 15 minutes. No difference was seen if unpurified bovine Fraction I (about 50 per cent clottable protein) or purified bovine Fraction I (90 to 95 per cent clottable protein) was used. Also, purified human Fraction I gave similar results. However, unpurified human Fraction I proved unsuitable for experimentation since it gave markedly concave curvature at low $\mathrm{X}^{2}$ values of the experimental IX vs. $\mathrm{X}^{2}$ graphs, thus making it impossible to obtain an accurate radius from the master curves. The reason for this is not definitely known but it may be because of the presence of cold-insoluble globulin (probably identical with cryoglobulin [24] and contractinogen [25]). Cold-insoluble globulin may be an impurity in human Fraction I which has

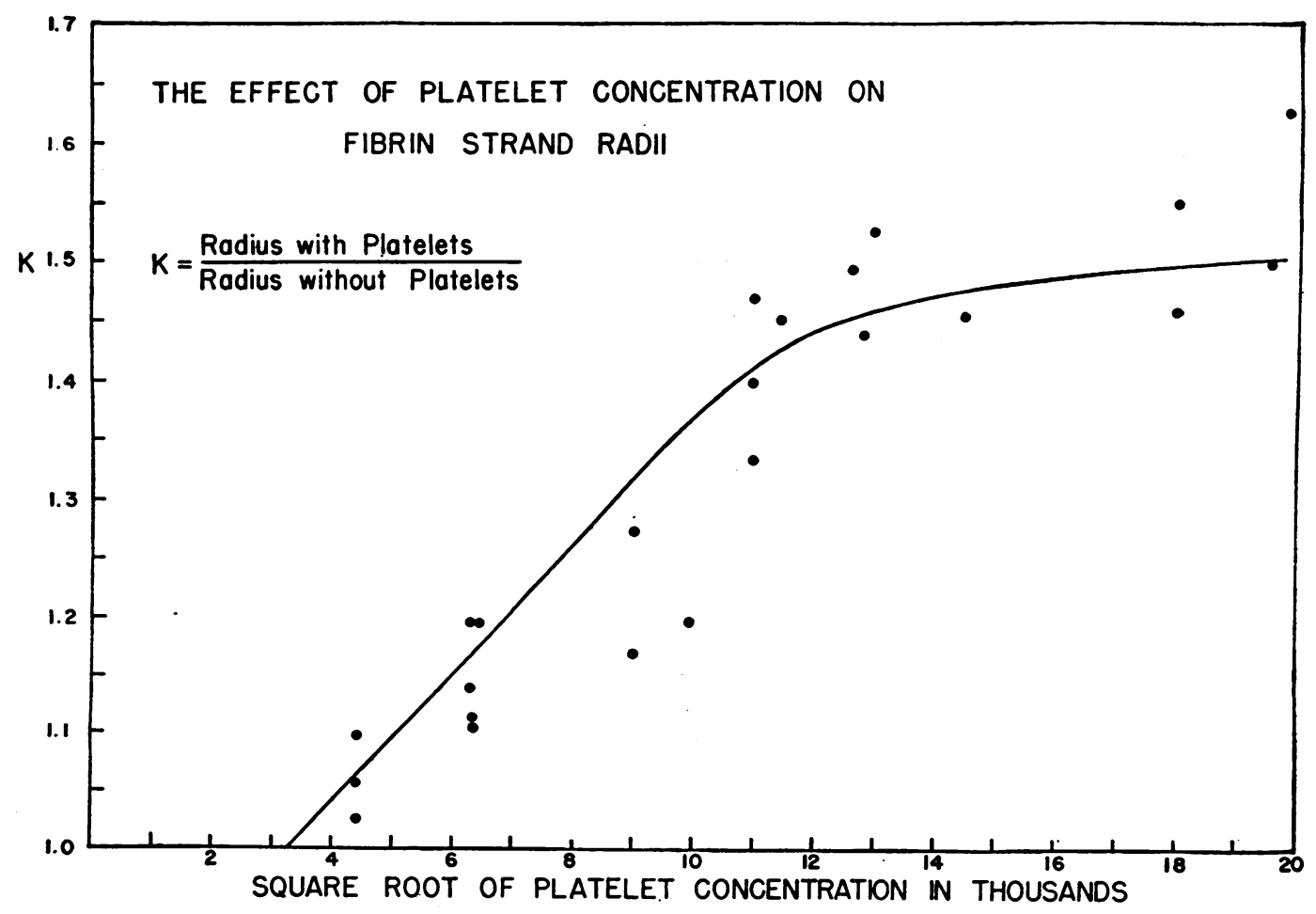

Fig. 2. The Effect of Platelet Concentration on Fibrin Strand Radit

The abscissa is the square root of platelet concentration in thousands, that is, 20 on the graph is equivalent to 400,000 platelets per $\mathrm{cu}$. $\mathrm{mm}$. 
been described (26) as forming a complex with fibrinogen on precipitation and it might well be incorporated in an unknown way in the clot structure.

\section{The effect of platelet concentration}

Washed human platelet suspensions of various platelet concentrations were added to bovine Fraction I preparations and the mixture clotted with thrombin-the final thrombin concentration being 0.3 units per cc. The readings were taken one hour after adding the thrombin at $24^{\circ}$ to $36^{\circ} \mathrm{C}$. and the fibrinogen concentration was fairly constant in all experiments varying between 0.24 and $0.32 \mathrm{gm}$. per liter. None of these clots retracted because there was no "serum factor" present. The ratio of the radius of the strands with platelets present to the radius of the strands with no platelets was designated as $\mathrm{K}$ and plotted against platelet concentration (Figure 2). The square root of the platelet concentration in thousands per cu. $\mathrm{mm}$. was used in order to make the graph more compact and in order to straighten out the parabola that otherwise occurs. Thus, " 20 " on the graph is equivalent to 400,000 platelets per cu. $\mathrm{mm}$. It is evident that with increasing platelet concentration the average fibrin radius increased between a lower limit of approximately 11,000 per cu. mm. and an upper limit of approximately 250,000 platelets per cu. $\mathrm{mm}$. at which point further increases in platelet concentration had little effect on the radius. There was no difference in the results on the increase of the fibrin strand radius if the platelets were prepared from citrated blood or from blood in which Sequestrene and Triton were used. However, with the Sequestrene and Triton, resuspension was easier and microscopically the platelets had less tendency to clump. One experiment was performed in which both thrombin concentration and platelet concentration were varied, and the effects of lowering the thrombin concentration and increasing the platelet concentration seem to be additive in increasing fibrin strand size.

\section{Correction of data for scattering from platelets}

The problem of correcting the experimental light scattering data of fibrin strands for the scattering due to the platelets presented a difficult theo-
TABLE II

The effect of different absolute radii of fibrin strands on the proportionate increase of the radii at three platelet concentrations

\begin{tabular}{cccc}
\hline \hline $\begin{array}{c}\text { Platelets } \\
\text { per } \\
\text { cu. mm. }\end{array}$ & $\begin{array}{c}\text { R in } \AA \\
\text { without } \\
\text { platelets }\end{array}$ & $\begin{array}{c}\text { R in } \AA \\
\text { with } \\
\text { platelets }\end{array}$ & $\begin{array}{c}\text { Propor- } \\
\text { tionate } \\
\text { increase } \\
\text { or K }\end{array}$ \\
\hline 40,000 & 505 & 605 & 1.20 \\
40,000 & 718 & 850 & 1.18 \\
80,000 & 605 & 766 & 1.27 \\
80,000 & 475 & 610 & 1.28 \\
120,000 & 600 & 815 & 1.36 \\
120,000 & 490 & 655 & 1.33 \\
\hline
\end{tabular}

retical and practical problem. ${ }^{8}$ Finally it was decided that for the following reasons no correction was necessary:

1. Platelets will give the same scattering pattern as fibrin strands with radii of approximately 700 Angstroms (27). Upon this hypothesis, an error due to the platelets would be falsely low if the radii of the fibrin strands were greater than 700 Angstroms-falsely high if the radii were less. There would be no error if the radii of the fibrin strands were exactly 700 Angstroms. However, in many different experiments, there was an appreciable difference in the absolute radii of the fibrin strands formed in the absence of platelets (Table II). In spite of this, the proportionate increase in the radius $(K)$ was essentially unchanged as long as the sample with platelets present contained the same platelet concentration. This was valid at several different platelet concentrations (Table II).

2. If the scattering due to platelets necessitated a correction, it would be reasonable to subtract the light scattering intensity readings of the unclotted fibrinogen solution containing platelets from the readings of the same solution which had clotted. However, in about half of the experiments the unclotted solutions scattered more light with a consequent higher reading than the same solution which had been clotted. Thus, by making a correction for the platelets, an impossible negative number would result. In those experiments with

8 It is deeply appreciated that Dr. Fred Bueche, formerly of Cornell University, Ithaca, N. Y., and more recently located at the University of Wyoming, Laramie, Wy., has continued to give advice on the light scattering aspects of this work. 
a positive result, in which a correction was possible, the calculated fibrin strand radii using this correction were less than 15 Angstroms. This likewise is an impossibility since the radius of the fibrinogen molecule is about 18 Angstroms (28). Representative experiments showing this phenomena are given in Table III. Only readings at one angle and one wave length (5460 Angstroms) are given for brevity although other angles and wavelengths show similar variations. These results show that at the same platelet concentration the observed intensity of scattering in the unclotted samples may vary markedly, indicating that any attempt to estimate platelet concentration simply by the amount of light scattered by them is not possible. Also shown in Table III are the observed intensity readings of the unclotted and clotted samples without platelets, again showing that the scattering from unclotted fibrinogen solutions without platelets is negligible compared to the scattering of the clot. Thus, the increased scattering of the unclotted sample containing platelets must be caused solely by the platelets. The above statements that the unclotted, plateletfree samples have no appreciable scattering apply only to the Fraction I preparation. If plasma is used, correction must be made for its preclotted scattering as described under Materials and Methods. The radii given in Table III are calculated only from the intensity readings of the clotted samples. The intensity readings of the unclotted samples are not used. It should be emphasized that, although the observed intensities recorded here are in Microvolts $\times 10^{-3}$, absolute units are unimportant since only relative values are necessary in the calculations (5). Since the scattering intensities of the unclotted samples are often quite different at the same platelet concentration, one would not expect identical $\mathrm{K}$ values if the platelets in the clotted sample were causing an appreciable error.

3. The decrease or insignificant increase of the intensity of scattering on clotting the samples containing platelets may be due to two phenomenathe platelets may disintegrate, or they may fuse to form large aggregates. If platelets fuse so that the aggregated particle has a diameter twice the diameter of the original single platelet, the intensity of scattering will be reduced by about one-tenth.

From the above evidence it is concluded that even though the contribution of the platelets to the scattering is largely unknown, this fact may not invalidate the method of calculating the fibrin strand width from the dissymmetry measurements. Because of the experiments described above in paragraphs one and two, because the results assumed a consistent pattern (Figure 2), and because there are theoretical reasons why such phenomena could occur (paragraph three), it appeared justified to make no correction for the scattering due to platelets in the fibrin clot. In the absence of absolute proof the evidence presented appears to support the validity of the above conclusion.

\section{The effect of clot retraction on fibrin radii}

The effect of clot retraction on the fibrin strand radii was measured with both bovine Fraction I

TABLE III

The effect of platelet concentration on proportionate increase in the radii of fibrin strands compared with the turbidity of the unclotted and clotted samples

\begin{tabular}{|c|c|c|c|c|c|c|c|}
\hline \multicolumn{4}{|c|}{ Observed intensity in microvolts $\times 10^{-3}$ at $\theta$ of $60^{\circ}$} & \multicolumn{2}{|c|}{ Clotted } & \multirow{3}{*}{$\begin{array}{l}\text { Platelets } \\
\text { per } \\
\text { cu. mm. }\end{array}$} & \multirow{3}{*}{$\begin{array}{c}\text { Proportionate } \\
\text { increase or } \\
\mathbf{K}\end{array}$} \\
\hline \multicolumn{2}{|c|}{ Without platelets } & \multicolumn{2}{|c|}{ With platelets } & \multirow{2}{*}{$\begin{array}{c}\mathrm{R} \text { in } \AA \\
\text { without } \\
\text { platelets }\end{array}$} & \multirow{2}{*}{$\begin{array}{c}\mathrm{R} \text { in } \AA \\
\begin{array}{c}\text { with } \\
\text { platelets }\end{array}\end{array}$} & & \\
\hline Unclotted & Clotted & Unclotted & Clotted & & & & \\
\hline $\begin{array}{l}0.2 \\
0.4\end{array}$ & $\begin{array}{l}18.3 \\
18.0\end{array}$ & $\begin{array}{l}19.2 \\
21.0\end{array}$ & $\begin{array}{l}24.3 \\
22.5\end{array}$ & $\begin{array}{l}485 \\
490\end{array}$ & $\begin{array}{l}514 \\
510\end{array}$ & $\begin{array}{l}20,000 \\
20,000\end{array}$ & $\begin{array}{l}1.06 \\
1.04\end{array}$ \\
\hline $\begin{array}{l}0.1 \\
0.3\end{array}$ & $\begin{array}{l}22.4 \\
24.0\end{array}$ & $\begin{array}{r}6.3 \\
23.5\end{array}$ & $\begin{array}{l}27.0 \\
29.3\end{array}$ & $\begin{array}{l}605 \\
588\end{array}$ & $\begin{array}{l}766 \\
748\end{array}$ & $\begin{array}{l}80,000 \\
80,000\end{array}$ & $\begin{array}{l}1.27 \\
1.27\end{array}$ \\
\hline $\begin{array}{l}0.2 \\
0.4\end{array}$ & $\begin{array}{l}18.3 \\
18.0\end{array}$ & $\begin{array}{l}42.6 \\
26.4\end{array}$ & $\begin{array}{l}25.0 \\
28.8\end{array}$ & $\begin{array}{l}485 \\
490\end{array}$ & $\begin{array}{l}660 \\
655\end{array}$ & $\begin{array}{l}120,000 \\
120,000\end{array}$ & $\begin{array}{l}1.36 \\
1.34\end{array}$ \\
\hline $\begin{array}{l}0.2 \\
0.4\end{array}$ & $\begin{array}{l}18.3 \\
18.0\end{array}$ & $\begin{array}{l}32.0 \\
46.5\end{array}$ & $\begin{array}{l}30.5 \\
33.0\end{array}$ & $\begin{array}{l}485 \\
490\end{array}$ & $\begin{array}{l}742 \\
735\end{array}$ & $\begin{array}{l}160,000 \\
160,000\end{array}$ & $\begin{array}{l}1.53 \\
1.50\end{array}$ \\
\hline
\end{tabular}


TABLE IV

The effect of clot retraction on fibrin radii

\begin{tabular}{|c|c|c|c|c|c|c|c|c|c|}
\hline \multirow[b]{2}{*}{$\begin{array}{l}\text { Fibrin } \\
\text { source }\end{array}$} & \multirow[b]{2}{*}{$\begin{array}{l}\text { Fibrin } \\
\text { conc. } \\
\text { g/L. }\end{array}$} & \multirow[b]{2}{*}{$\begin{array}{l}\text { Thrombin } \\
\text { conc. } \\
u / c c .\end{array}$} & \multirow[b]{2}{*}{$\mathrm{pH}$} & \multirow[b]{2}{*}{$\begin{array}{l}\text { Platelets } \\
\text { per } \\
\text { cu. mm. }\end{array}$} & \multirow[b]{2}{*}{$\begin{array}{c}\mathbf{R} \text { in } \AA \\
\text { before } \\
\text { retraction }\end{array}$} & \multicolumn{3}{|c|}{ After retraction } & \multirow[b]{2}{*}{$\begin{array}{c}\text { Proportion } \\
\text { increase of } \\
\mathbf{K}\end{array}$} \\
\hline & & & & & & $\underset{\AA}{R_{\text {in }}^{\text {in }}}$ & $\begin{array}{c}\text { Est. } \\
\%\end{array}$ & $\begin{array}{c}\text { Time } \\
\text { in } \\
\text { min. }\end{array}$ & \\
\hline $\begin{array}{l}\text { Bovine } \\
\text { Fraction } \\
\quad \text { I }\end{array}$ & $\begin{array}{l}0.25 \\
1.20 \\
1.20\end{array}$ & $\begin{array}{l}.3 \\
.3 \\
.3\end{array}$ & $\begin{array}{l}7.23 \\
7.10 \\
7.10\end{array}$ & $\begin{array}{r}120,000 \\
25,000 \\
124.000\end{array}$ & $\begin{array}{l}740 \\
785 \\
815\end{array}$ & $\begin{array}{l}810 \\
810 \\
825 \\
830\end{array}$ & $\begin{array}{l}70 \\
20 \\
30 \\
40\end{array}$ & $\begin{array}{r}120 \\
120 \\
90 \\
120\end{array}$ & $\begin{array}{l}1.09 \\
1.03 \\
1.01 \\
1.01\end{array}$ \\
\hline Plasma & 0.23 & .3 & 8.20 & 25,000 & 815 & $\begin{array}{l}850 \\
870\end{array}$ & $\begin{array}{l}20 \\
30\end{array}$ & $\begin{array}{r}90 \\
120\end{array}$ & $\begin{array}{l}1.04 \\
1.07\end{array}$ \\
\hline Plasma & 0.21 & .02 & 8.20 & 23,250 & 850 & $\begin{array}{l}865 \\
865\end{array}$ & $\begin{array}{l}20 \\
40\end{array}$ & $\begin{array}{l}100 \\
120\end{array}$ & $\begin{array}{l}1.02 \\
1.02\end{array}$ \\
\hline Plasma & 0.21 & .3 & 8.20 & 23,250 & 700 & 690 & 35 & 135 & 0.99 \\
\hline Plasma & 0.21 & .3 & 8.20 & 23,250 & 750 & 750 & 20 & 150 & 1.00 \\
\hline
\end{tabular}

plus added platelets and with fresh citrated plasma diluted with $0.15 \mathrm{M}$ sodium chloride solution (Table IV). The clots did not begin to retract until more than one hour after adding thrombin had elapsed, hence the measurements of the strand size of the unretracted clots were made one hour after adding the thrombin. Attempts were made to accurately measure the amount of retraction by draining off the free fluid but it soon was apparent that estimation by simple inspection gave equally reliable results. Again, no correction was made for scattering due to platelets as discussed above. Some experiments were unsuitable for light scattering readings because the clots did not retract symmetrically and hence the optical system was inaccurate. Whenever this occurred the sample was discarded. The ratio of the radii of the strands of the retracted clot to the radii of the unretracted clot was designated as $\mathrm{K}$. Although the radius was increased slightly in all but two experiments, in none was the increase comparable to that shown with variations in thrombin or platelet concentration. In fact, in all but one, the increases were within experimental error (5), 7 per cent or $\mathrm{K}=1.07$.

\section{Solubility of clots in urea}

It is of interest that all of these clots formed by adding thrombin to Fraction I or plasma dissolved easily in 30 per cent urea. Most of the clots which contained platelets also dissolved, although occasionally a few particles of undissolved clot remained. Retracted clots dissolved equally as well as unretracted clots. However, clots formed by the recalcification of citrated or oxalated plasma were urea insoluble. Recalcified clots in general have thicker strands than clots formed from the addition of thrombin to the plasma (29). The time of clotting is significantly longer when plasma is clotted by recalcification than when it is clotted by adding thrombin. And the amount of thrombin formed by recalcifying plasma cannot be easily measured. Therefore, no further quantitative experiments have been carried out on clots formed by this method.

\section{DISCUSSION}

In 1947, Ferry and Morrison (3) stated that increasing thrombin concentration diminishes the clotting time and gives thinner fibrin strands because of an increase of the ratio of "the reaction rate to the translational and rotational diffusion rates of fibrinogen molecules." This was compared to the growth of crystals; the slower the rate of growth the larger the resulting crystals. In spite of the fact that the kinetics of the fibrinogen-fibrin reaction $(30,31)$ and the theories of crystal growth (32) have been well studied, a precise mathematical statement describing fibrin formation still cannot be formulated because of the lack of knowledge of the basic chemical reactions involved in the polymerization process. It now seems evident that the "primary" action of thrombin may be proteolytic (33), and by its action an 
altered (or activated) fibrinogen molecule results (34-37). The fibrinogen molecules then combine so that long and thick fibers form (38). However, the nature of the bonds is not yet definitely known. The ability of urea to dissolve certain fibrin clots suggests that hydrogen bonds (39) are involved-but the bond energies of hydrogen bridges are so low (about $1 / 10$ as strong as most covalent bonds [40]) that probably hundreds would be necessary for each molecule. This would imply an improbably close alignment of each fibrinogen molecule to the next. Most workers (41, 42) agree that amino groups and perhaps carbohydrate groups, not sulfhydryl groups, are involved in the bond. Recent studies have been carried out on inhibited clotting systems $(36,43,44)$ where the polymerization of fibrinogen is retarded by the presence of hexamethylene glycol, so that various measurements can be made of partially polymerized fibrinogen. This work indicates that "the fundamental process of attachment (of fibrinogen molecules) is lateral dimerization with partial overlapping which, when repeated, leads to two parallel end-to-end chains with staggered junctions" (43). Future studies of this type may lead to a basic understanding of the polymerization of fibrinogen. It should be emphasized that plasma clots formed in the presence of the serum factor and calcium ion are urea-insoluble (45) and hence differ from the clots derived from purified fibrinogen and thrombin preparations. The nature of the serum factor, or "urea insolubility factor," and the specificity of the calcium ion has been further studied by Loewy (46) but the part that these two substances play in altering the final clot is not yet known. It is difficult to compare the electron microscope findings of Morrison and Scudder (4) with this investigation. They found no change in fibrin strand width with the variation of thrombin concentration between .01 to 1.0 unit per cc. They formed their clots at $\mathrm{pH} 6.4$ and a fibrinogen concentration of $1.0 \mathrm{gm}$. per liter. However, these authors state that a certain amount of doubt is cast on the interpretation of all work of this type due to the limitations of the technique which requires a very thin film of the reactants.

The exact role of platelets on fibrin formation has been controversial since Donné first described them in $1842(47,48)$. Hayem, in 1878 (49), originated the concept that platelets were necessary for clot retraction. Tocantins (13), using a light microscope and hemophilic plasma, stated that the fibrin strands formed in platelet-free plasma were twice as long and thick as in platelet rich plasma. However, these platelet-free clots took much longer to form and the thrombin concentration was not controlled. Best, Cowan, and Maclean (50), Pinniger and Prunty (14) and Budtz-Olsen (7), using a light microscope, and Wolpers and Ruska (15), Braunsteiner, Febvre, and Klein (16), and Jürgens (51), using an electron microscope all came to the conclusion that the fibrin clot structure was the same whether or not platelets were present. Mann, Hurn, and Mathieson (52) also found that first the fibrin clot is formed; then the platelets become attached to the clot. Almost all workers now agree that intact platelets are necessary for clot retraction, and some workers believe that either the amount (53) or rate (54) of retraction is related to the adhesiveness of platelets. Fonio (55) has demonstrated that the clot retracting ability of the platelet resides in its hyalomere.

Stefanini (56) in his recent review on blood coagulation summarized the various theories on the action of platelets in accelerating the conversion of prothrombin to thrombin. In these experiments in which no prothrombin is present there is no possibility for such an action to occur. However, Ware, Fahey, and Seegers (57) first described a property of platelet extracts which accelerates the action of thrombin on fibrinogendesignated as platelet factor 2. This work was confirmed by Van Creveld and Paulssen (58). Horányi (59) restudied the dual role of platelets and concluded that upon coagulation some of the platelets disintegrate increasing the net amount (or here, activity) of thrombin while the remainder of the platelets remain intact to function in the retraction of the clot. Therefore, the fewer destroyed, the greater the retraction (60). The effect of platelet disintegration is that it may increase local thrombin concentration and may thus partially contradict the previous observation that the greater the thrombin concentration, the smaller the fibrin strands. The relation of the migration of platelets to strands of fibrin already formed can only be hypothesized (13). It may result in less 


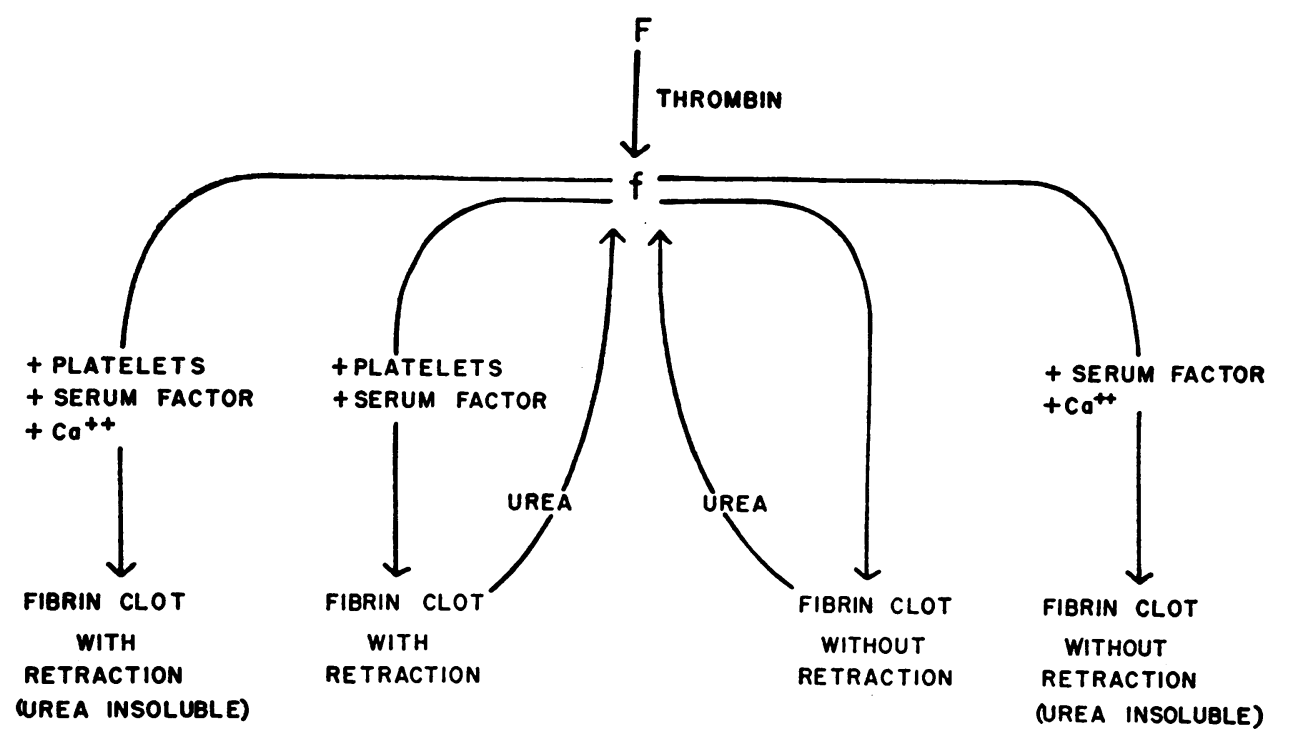

Fig. 3. Rrlation of Clots Which Are or Are Not Urea Soluble with Clots Which Do or Do Not Retract

The serum factors may be identical substances.

numerous but thicker strands per unit weight of fibrin.

The lack of the increase in thickness of the fibrin strands upon retraction of the clot is consistent with the observations of other workers in this field $(7,13)$. They believe that after coagulation, the platelets which either acted as foci for laying the fibrin network or migrated to the fibrin strands, become attached $(14,61)$ to the fibrin and then begin to fuse together (viscous metamorphosis $[50,62,63]) .^{9}$ As this fusion of the platelets continues, the fibrin network is drawn together to give the phenomena of clot retraction. Since the fibrin strands are not involved in this process, their sizes remain unchanged. The energy for this process seems to originate from the "living" (66, 67) platelets. Thus, during clotting, some platelets disintegrate, others fuse together. Either, or both of these phenomena would decrease the light scattering in the clot due to the platelets, as previously discussed under "Correction of Data for Scattering from Platelets."

The extact relation between the "serum factor" necessary for the formation of urea insoluble clots and the "serum factor" necessary for clot re-

9 This process of viscous metamorphosis is considered to be quite distinct from platelet agglutination seen in some patients with idiopathic thrombocytopenic purpura $(64,65)$. traction is not clear. Clots formed in the absence of calcium ions will retract if platelets and the serum factor are present. In this investigation, the behavior of the clots toward urea agrees with Laki and Lóránd (68). The urea solubility of the clots is probably effected by the lowering of the calcium ion concentration below a critical level-this low calcium ion concentration in Fraction I resulting from the phosphate buffer used in the adjustment of the $\mathrm{pH}$ and the ionic strength, and in plasma from the citrate used as an anticoagulant. If imidazole buffer (69) was used and an extra amount of calcium ion added, urea insoluble clots were obtained from the unpurified bovine Fraction I. Since urea soluble clots, which are formed in the absence of calcium ions and in the presence of platelets and serum factor, will retract, it seems reasonable to assume that the serum factor in this situation merely increased the viscous metamorphosis of the platelets as described by Wright and Minot 36 years ago (62). It is also reasonable to assume that the fibrin stucture was the same as though the serum factor and platelets had been absent. However, if the calcium ion and a serum factor are present, urea insoluble clots result which retract when platelets are also in the clotting mixture. These interrelations are diagrammatically represented in Fig- 
ure 3 , where $F$ represents fibrinogen ${ }^{10}$ and $f$ is activated fibrinogen (probably native fibrinogen from which a peptide has been split-see above). The actual difference between these two types of fibrin (urea soluble or insoluble) is probably in the type of bond. With the calcium and serum factor present, the urea insoluble clot is stronger $(70,71)$ than the urea soluble clot. The calcium ion is not firmly bound to the fibrin clot-stronger bonds being formed in the primary polymerization process (72). Clearly the retraction of the clot is independent of the fibrin structure and only depends on platelet fusion to draw the fibrin strands together-the fibrin strands remaining passive in the process.

\section{SUM MARY}

Purified fibrinogen solutions and plasma preparations were clotted with various concentrations of thrombin, both with and without platelets present in the clotting mixture. The radii of the fibrin strands were measured using a light scattering method and it was shown that:

1. Decreasing the thrombin concentration resulted in wider fibrin strands.

2. Increasing the platelet concentration resulted in wider fibrin strands.

3. Clot retraction did not significantly alter the width of the fibrin strands.

\section{ACKNOWLEDGMENTS}

The author wishes to express sincere appreciation to Dr. Engene L. Lozner for advice and criticism. He also wishes to thank Dr. John T. Edsall for his suggestions with regard to the clarification of the manuscript.

\section{REFERENCES}

1. Stübel, H., Ultramikroskopische studien über Blutgerinnung und Thrombocyten. Pflüger's Arch. f. d. ges. Physiol., 1914, 156, 361.

2. Howell, W. H., The clotting of blood as seen with the ultramicroscope. Am. J. Physiol., 1914, 35, 143.

3. Ferry, J. D., and Morrison, P. R., Preparation and properties of serum and plasma proteins. VIII. The conversion of human fibrinogen to fibrin un-

10 The notation used is that adopted by other workers $(36,43)$. The intermediate polymers between activated fibrinogen and fibrin which these workers have studied have been omitted here for clarity. der various conditions. J. Am. Chem. Soc., 1947, 69, 388.

4. Morrison, P. R., and Scudder, C. L., Fibrin clot structure during clotting as observed in unsupported films under electron microscope. Am. J. Physiol., 1952, 170, 147.

5. Greene, R. W., Light scattering studies of fibrin clots. J. Clin. Invest., 1952, 31, 969.

6. Quick, A. J., and Hussey, C. V., The mechanism of clot retraction. Science, 1950, 112, 558.

7. Budtz-Olsen, O. E., Clot Retraction. Springfield, Ill., Charles C Thomas, 1951.

8. Quick, A. J., The hemorrhagic diseases and the physiology of hemostasis. Springfield, Ill., Charles C Thomas, 1942.

9. Ellicott, C. E., and Conley, C. L., Retraction of clots formed from purified fibrinogen. Bull. Johns Hopkins Hosp., 1951, 88, 321.

10. Lampert, H., Die Physik der Blutgerinnung. Kolloid-Z., 1932, 60, 3.

11. Ebbeke, U., and Knüchel, F., Uber die strukter des fibringerüsts bei der gerinnung. Pflüger's Arch. f. d. ges. Physiol., 1939, 243, 65.

12. Ebbeke, U., Uber die fibringerinnung als polymerisations-kristalisationsvorgang. Biochem. Ztschr., 1940, 304, 177.

13. Tocantins, L. M., Platelets and the structure and physical properties of blood clots. Am. J. Physiol., 1936, 114, 709.

14. Pinniger, J. L., and Prunty, F. T. G., Some observations on the blood-clotting mechanism. The role of fibrinogen and platelets, with reference to a case of congenital afibrinogenaemia. Brit. J. Exper. Path., 1946, 27, 200.

15. Wolpers, C., and Ruska, H., Strukturenuntersuchumgen zur blutgerinnung. Klin. Wchnschr., 1939, 18, $1077,1111$.

16. Braunsteiner, H., Febvre, H. L., and Klein, R., Observation des thrombocytes au microscope electronique et etude de leurs rapports avec la coagulation à l'état normal et dans quelques etats pathologiques in Proc. 3rd Int. Congress of Int. Soc. Hematology, New York, Grune \& Stratton, 1951, pp. 511-513.

17. Laki, K., The polymerization of proteins: The action of thrombin on fibrinogen. Arch. Biochem. \& Biophys., 1951, 32, 317.

18. Seegers, W. H., and Smith, H. P., Factors which influence the activity of purified thrombin. Am. J. Physiol., 1942, 137, 348.

19. Ferguson, J. H., Discussion in Blood clotting and allied problems. J. E. Flynn, Ed., Trans. Second Conf. New York, Josiah Macy, Jr. Foundation, 1949, pp. 141-142.

20. Dillard, G. H. L., Brecher, G., and Cronkite, E. P., Separation, concentration, and transfusion of platelets. Proc. Soc. Exper. Biol. \& Med, 1951, 78, 796. 
21. Minor, A. H., and Burnett, L., A method for separating and concentrating platelets from normal human blood. Blood, 1952, 7, 693.

22. Thorsén, G., and Hint, H., Aggregation, sedimentation and intravascular sluging of erythrocytes, interrelation between suspension stability and colloids in suspension fluid. An experimental study. Acta chir. Scandinav., 1950, Supp. 154, 1.

23. Morrison, P. R., Preparation and properties of serum and plasma proteins. XV. Some factors influencing the quantitative determination of fibrinogen. $\mathrm{J}$. Am. Chem. Soc., 1947, 69, 2723.

24. Barr, D. P., Reader, G. G., and Wheeler, C. H., Cryoglobulinemia. I. Report of two cases with discussion of clinical manifestations, incidence, and significance. Ann. Int. Med., 1950, 32, 6.

25. Morrison, I. R., Qualitative changes in fibrinogen which influence the erythrocyte sedimentation rate and the clot retraction time. Am. J. M. Sc., 1946, 211, 325.

26. Morrison, P. R., Edsall, J. T., and Miller, S. G., Preparation and properties of serum and plasma proteins. XVIII. The separation of purified fibrinogen from Fraction I of human plasma. J. Am. Chem. Soc., 1948, 70, 3103.

27. Bueche, F., Personal communication.

28. Edsall, J. T., Foster, J. F., and Scheinberg, H., Studies on double refraction of flow. III. Human fibrinogen and Fraction I of human plasma. J. Am. Chem. Soc., 1947, 69, 2731.

29. Greene, R. W., Unpublished observations.

30. Waugh, D. F., and Livingstone, B. J., Clotting time and reaction velocity in the interaction of bovine fibrinogen and thrombin. Science, 1951, 113, 121.

31. Waugh, D. F., and Patch, M. J., The effects of ionic strength on the interaction of bovine fibrinogen and thrombin. J. Phys. Chem., 1953, 57, 377.

32. Tipson, R. S., Crystallization and recrystallization. Chapt. VI. in Technique of Organic Chemistry. A. Weissberger, ed., New York, Interscience Publishers, Inc., 1950, vol. 3.

33. Sherry, S., and Troll, W., The nature of the action of thrombin. Enzymatic attack on a synthetic substrate. J. Clin. Invest., 1953, 32, 603 (Abstract).

34. Laki, K., and Mommaerts, W. F. H. M., Transition of fibrinogen to fibrin as a two-step reaction. Nature, 1945, 156, 664.

35. Ehrlich, P., Shulman, S., and Ferry, J. D., The conversion of fibrinogen to fibrin. VIII. Sedimentation and viscosity studies on clotting systems inhibited by urea and on solutions of fibrin in urea. J. Am. Chem. Soc., 1952, 74, 2258.

36. Backus, J. K., Laskowski, M., Jr., and Scheraga, H. A., Distribution of intermediate polymers in the fibrinogen-fibrin conversion. Arch. Biochem. \& Biophys., 1952, 41, 354.

37. Ferry, J. D., Consideration of the structure and mechanism of formation of the fibrin clot in Blood
Clotting and Allied Problems, J. E. Flynn, Ed, Trans. Second Conf. New York, Josiah Macy, Jr. Foundation, 1949, pp. 84-105.

38. Steiner, R. F., and Laki, K., Light scattering studies on the clotting of fibrinogen. Arch. Biochem. \& Biophys., 1951, 34, 24.

39. Mihályi, E., Properties of fibrin dissolved in urea solutions. Acta chem. Scandinav., 1950, 4, 344.

40. Pauling, L., The Nature of the Chemical Bond. Ithaca, N. Y., Cornell University Press, 1940.

41. Edsall, J. T., Some unsolved problems in the chemistry of blood clotting in Blood Clotting and Allied Problems, J. E. Flynn, Ed., Trans. First Conf. New York, Josiah Macy, Jr. Foundation, 1948, pp. $49-63$.

42. Laki, $K$, The transition of fibrinogen to fibrin in Blood Clotting and Allied Problems, J. E. Flynn, Ed., Trans. Fourth Conf. New York, Josiah Macy, Jr. Foundation, 1951, pp. 217-260.

43. Ferry, J. D., Shulman, S., Gutfreund, K., and Katz, S., The conversion of fibrinogen to fibrin. XI. Light scattering studies on clotting systems inhibited by hexamethylene glycol. J. Am. Chem. Soc., 1952, 74, 5709.

44. Kaesberg, P., and Shulman, S., Electron microscope observations on intermediate polymers in the conversion of fibrinogen to fibrin. J. Biol. Chem., 1953, 200, 293.

45. Lóránd, L., Fibrin clots. Nature, 1950, 166, 694.

46. Loewy, A. G., Observations discussed by Edsall, J. T., in (42).

47. Tocantins, L. M., Historical notes on blood platelets. Blood, 1948, 3, 1073.

48. Donné, A., Del'origine des globules du sang, de leur mode de formation et de leur fin. Compt. rend. Acad. d. sc., 1842, 14, 366.

49. Hayem, G., Recherches sur l'évolution des hématies dans le sang de l'homme et des vertébrés. Arch. Physiol. Norm. et Path., 1878, 5, 692.

50. Best, C. H., Cowan, C., and Maclean, D. L., Heparin and the formation of white thrombi. J. Physiol., 1938, 92, 20.

51. Jürgens, R., Experimental investigations on the agglutination of thrombocytes in Proc. 3rd Int. Congress of Int. Soc. Hematology. New York, Grune \& Stratton, 1951, pp. 514-523.

52. Mann, F. D., Hurn, M., and Mathieson, D. R., Platelets as foci in the coagulation of blood. Am. J. Physiol., 1949, 158, 84.

53. Still, B. M., Experiments on plasma clot contraction. Blood, 1952, 7, 808.

54. Savitsky, J. P., and Werman, R., Platelet adhesiveness and clot-retraction time. Am. J. Clin. Path., 1952, 22, 1175.

55. Fonio, A., Neuere untersuchungen über die physiologie der thrombozyten in Proc. 3rd Int. Congress of Int. Soc. Hematology. New York, Grune \& Stratton, 1951, pp. 523-528. 
56. Stefanini, M., Seminars on blood coagulation; mechanism of blood coagulation in normal and pathologic conditions. Am. J. Med., 1953, 14, 64.

57. Ware, A. H., Fahey, J. L., and Seegers, W. H., Platelet extracts, fibrin formation and interaction of purified prothrombin and thromboplastin. Am. J. Physiol., 1948, 154, 140.

58. Van Creveld, S., and Paulssen, M. M. P., Significance of clotting factors in blood-platelets, in normal and pathological conditions. Lancet, 1951, 2, 242.

59. Horanyi, M., Studies on the retraction of the blood clot. Acta. med. Scandinav., 1951, 140, 140.

60. Tocantins, L. M., The mammalian blood platelet in health and disease. Medicine, 1938, 17, 155.

61. Fonio, A., Beobachtungen über den Gerinnungs- und den thrombosevor-gang im dunkelfeldnativpräparat. Schweiz. med. Wchnschr., 1940. 21, 510.

62. Wright, J. H., and Minot, G. R., The viscous metamorphosis of the blood platelets. J. Exper. Med., 1917, 26, 395.

63. Ferguson, J. H., Observations on the alterations of blood platelets as a factor in coagulation of the blood. Am. J. Physiol., 1934, 108, 670.

64. Stefanini, M., Dameshek, W., and Adelson, E., Platelets: VII. Shortened "platelet survival time" and development of platelet agglutinins following multiple platelet transfusions. Proc. Soc. Exper. Biol. \& Med., 1952, 80, 230.

65. Harrington, W. J., Sprague, C. C., Minnich, V., Moore, C. V., Aulvin, R. C., and Dubach, R., Immunologic mechanisms in idiopathic and neo- natal thrombocytopenic purpura. Ann. Int. Med, 1953, 38, 433.

66. Alexander, B., and Goldstein, R., Studies with bloodclotting components obtained by new process of blood collection, employing exchange resin for decalcification in Separation of the Formed Elements, the Protein, Carbohydrate, Lipid, Steroid, Peptide and Other Components of Plasma. First Proc. of the University Lab. of Physical Chem. Related to Medicine and Public Health, July 11, 1950. Cambridge, Mass., Harvard University, 1951, pp. 89-113.

67. Mackay, W., The blood-platelet: Its clinical significance. Quart. J. Med., 1931, 24, 285.

68. Laki, K., and Lóránd, L., On the solubility of fibrin clots. Science, 1948, 108, 280.

69. Mertz, E. T., and Owen, C. A., Imidazole buffer: its use in blood clotting studies. Proc. Soc. Exper. Biol. \& Med., 1940, 43, 204.

70. Wagreich, H., and Tarlov, I. M., Studies on the strength of fibrinogen-thrombin clots. Arch. Biochem., 1945, 7, 345.

71. Ferry, J. D., Miller, M., and Shulman, S., The conversion of fibrinogen to fibrin. VII. Rigidity and stress relaxation of fibrin clots; effect of calcium. Arch. Biochem. \& Biophys., 1951, 34, 424.

72. Katz, S., Shulman, S., Tinoco, I., Jr., Billick, I. H., Gutfreund, K., and Ferry, J. D., The conversion of fibrinogen to fibrin. XIV. The effect of calcium on the formation and dissociation of intermediate polymers. Arch. Biochem. \& Biophys., 1953, 47, 165. 